\title{
Gibbsite Solubility in Hanford High-Level Nuclear Waste Approached from Above and Below Saturation.
}

\author{
By \\ Jacob G. Reynolds, Jacob K. McCoskey, and Daniel L. Herting \\ Washington River Protection Solutions, LLC. P.O. Box 850 \\ Richland, WA, 99352
}

\section{Introduction:}

The purpose of this section is to tabulate the gibbsite solubility data in $\mathrm{NaOH}(\mathrm{aq})$ solutions measured in this study. Table S1 contains the measured concentrations of aluminum, sodium, and hydroxide molality at equilibrium. The density is also provided, which was used for converting the data from micrograms per liter to molality. All of the cations and anions were measured, so the charge balance discrepancy can be calculated as an indicator of the quality of the data. Sample one and three had good charge balance. The charge balance of sample 2 was larger $(13 \%)$ which is consistent with Figure 3 of the text. Figure 3 shows that sample 2 does not follow the trend of Russell et al.'s (1955) data as well as samples 1 and 2. Nonetheless, all three data points are much more similar to Russell et al's (1955) data than the real waste supernatant liquid data. This indicates that sample discrepancies are not responsible for the different behavior of real waste and simple $\mathrm{NaOH}(\mathrm{aq})$ solutions. 
Table S1. Gibbsite Solubility in $\mathrm{NaOH}(\mathrm{aq})$ Solution at $40{ }^{\circ} \mathrm{C}$ Determined in this Study.

\begin{tabular}{|c|c|c|c|c|c|c|}
\hline Sample & Density $(\mathrm{g} / \mathrm{mL})$ & Al Molality & $\begin{array}{l}\mathrm{Na} \\
\text { Molality }\end{array}$ & $\begin{array}{l}\text { Hydroxide } \\
\text { Molality } \\
\end{array}$ & $\begin{array}{l}\text { Charge } \\
\text { Balance } \\
\text { Discrepancy } \\
\text { (mol/Kg) } \\
\end{array}$ & $\begin{array}{l}\text { Charge Balance } \\
\text { Discrepancy as a } \\
\% \text { of } \mathrm{Na} \\
\text { Concentration }\end{array}$ \\
\hline 1 & 1.068 & 0.189 & 1.641 & 1.369 & 0.083 & 5.06 \\
\hline 2 & 1.121 & 0.359 & 3.315 & 2.5 & 0.456 & 13.76 \\
\hline 3 & 1.173 & 0.596 & 4.196 & 3.544 & 0.056 & 1.33 \\
\hline
\end{tabular}

